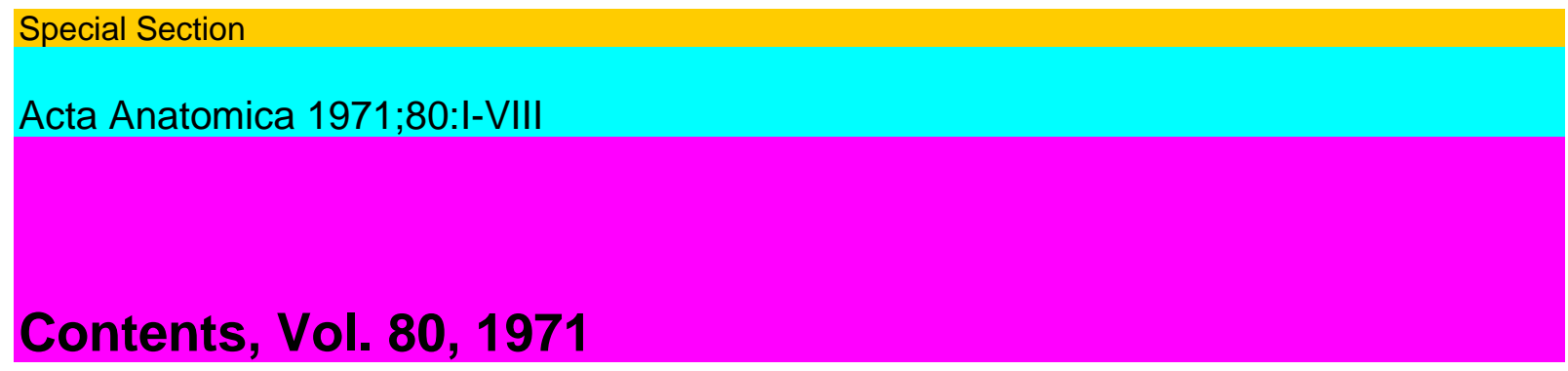

Redactores:

E.A. Boyden, Seattle,

Wash. A. Delmas, Paris F.Walberg, Oslo G. Wolf-Heidegger, Basel

Editores:

W. E. Adams, Dunedin,

N.Z. R.Amprino, Bari J.Ariens Kappers,

Amsterdam W. Bargmann, Kiel J.A.Baumann, Geneve N. J.Berril, Montreal P. Bodian,

Baltimore, Md. G.Boehm, Basel W. Brandt!, Birmingham A. Brodal, Oslo L. Bucciante, Padova

0. Bucher, Lausanne W.Buno, Montevideo T. Caspersson, Stockholm K. S. F. Chang, Hongkong

M. Chevremont, Liege R. Courrier, Paris E.V. Cowdry, St. Louis, Mo. A.Dalcq, Bruxelles J.

Dankmeijer, Leiden L. J. A. Di Dio, Toledo, Ohio G. Dubreuil, Bordeaux L. Einarson, Aarhus

O.Eranko, Helsinki Z. Erenqin, Ankara A. Faller, Fribourg

D.W. Fawcett, Boston,

Mass. W. U. Gardner,

New Haven, Conn. A. Giroud, Paris P. Glees, Gottingen St. Grzycki, Lublin A. Hadjioloff, Sofia

G. Haggqvist, Stockholm A.W. Ham, Toronto G. C. Heringa, Amsterdam M. IcKOWiczf, Jerusalem B.E. Ingelmark, Goteborg J. Jansen, Oslo N. A. Javachishvili, Tbilisi D. jDANOwf, Moskwa Ch. A. Joel, Tel Aviv D. Kadanoff, Sofia G. Leplat, Liege R. Locchi, Sao Paulo M.

Lucien, Nancy E.LuDWiGf, Basel K. S. Ludwig, Aachen O.Machado de Sousa,

Sao Paulo t). Maskar, Istanbul R. Miline, Novi Sad G. A. G. Mitchell,

Manchester M. Mori, Fukuoka O.M. Olivo, Bologna F. Orts Llorca, Madrid N. Pesonen,

Helsinki T. Petren, Stockholm A. Policard, Paris A. Portmann, Basel

M. Reicher, Gdansk B. Romeis, Miinchen

E. C. Roosen-Runge,

Seattle, Wash.

F. Rossi, Genova

A. Savas, Saloniki

H. G. Schwarzacher, Wien

E. Seiferle, Zurich

H. Selye, Montreal

H. Seto, Sendai

V. Simic, Beograd

J. M. Sosa, Merida

J. Stanek, Bratislava

D. Starck, Frankfurt a. M. 
S. Stchelvunow, Leningrad

J. Steffensen, Reykjavik

$\mathrm{Ph}$. Stohr, Bonn

A. Studitski, Moskwa

J. Sunderland, Melbourne

J. Szentagothai, Budapest

A. A.Tarkhan, Cairo

G.Tondtjry, Zurich

I.Toro, Debrecen

J.Turchini, Montpellier

J.Verne, Paris

P.Weiss, New York, N.Y.

D. M. Whitaker,

New York, N.Y. M.W.Woerdeman,

Amsterdam J.Wolf, Praha M.Wrete, Uppsala J. M. Yoffey, Jerusalem J. Z.Young, London Z. Zeren, Istanbul K. Zlabek, Brno

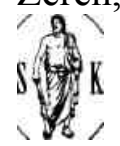

S. Karger $\bullet$ Basel $\bullet$ Miinchen $\bullet$ Paris $\bullet$ London $\bullet$ New York $\bullet$ Sydney

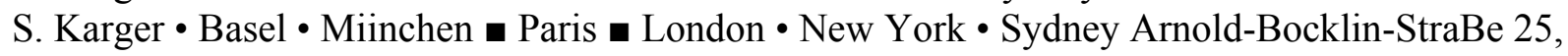
CH-4000 Basel 11 (Switzerland)

All rights, including that of translation into other languages, reserved. Photomechanic

reproduction (photocopy, microcopy) of this volume or parts thereof without special permission of the publishers is prohibited.

(C) Copyright 1971 by S. Karger AG, Verlag fiirMedizinundNaturwissenschaften, Basel Printed in Switzerland by Basler Druck- und Verlagsanstalt, Basel Cliches: Steiner \& Cie., AG, Basel Contents

Ahmed, M.M.: vide Kanagasuntheram, R.

Aiello-Malmberg, P.: vide Amprino, R.

Amprino, R. and Aiello-Malmberg, P. (Bari): Digit formation from the

prospective stylozeugopod of the hind-limb in the chick 183

Atsumi, S. (Tokyo): The histogenesis of motor neurons with special reference to the correlation of their endplate formation. I. The development of endplates in the intercostal muscle in the chick embryo. ... 161

Atsumi, S. (Tokyo): The histogenesis of motor neurons with special reference

to the correlation of their endplate formation. II. The localization

of motor neurons innervating the intercostal muscle in the thoracic

cord in the chicken 321

Atsumi, S. (Tokyo): The histogenesis of motor neurons with special reference

to the correlation of their endplate formation. III. The develop

ment of motor neurons innervating the intercostal muscle in the

chick embryo 504

Bandaranayake, R.C. (London): Morphology of the accessory neurosecre

tory nuclei and of the retrochiasmatic part of the supraoptic nucleus

of the rat

14 
Bhargava, I.; Chakravarty, A. and Raja, P.T.K. (Bhopal): An ana tomical study of the foetal blood vessels on the chorial surface of the human placenta 465

Bhargava, I.; Chakravarty, A. and Raja, P.T.K. (Pondicherry): Ana tomy of foetal blood vessels on the chorial surface of the human placenta. IV. With absence of one umbilical artery 620 Bugge, J. (Aarhus): The cephalic arterial system in sciuromorphs with spe cial reference to the systematic classification of rodents 336 Bugge, J. (Aarhus): The cephalic arterial system in New and Old World hystricomorphs, and in bathyergoids, with special reference to the systematic classification of rodents $\quad 516$ Cerveny, C.: vide Kaman, J.

Chakravarty, A.: vide Bhargava, I.

Chan, H. L.: vide Kanagasuntheram, R.

Chin, K. N.: vide Wong, W. C.

Choudhury, S. R. (Manchester): Neurosecretory mechanism: hypothalamoneuro-hypophysial inter-relationship 136

Csillik, B.; Jancso, G.; Toth, L.; Kozma, M.; Kalman, G. and Karcsu, S. (Szeged): Adrenergic innervation of hypothalamic blood vessels. A contribution to the problem of central thermodetectors .... 142

Das Gupta, T.K.; Moss, G.S. and Newson, B. (Chicago): Localization of sodium ion in the normal primate lung $\quad 426$

Contents VI

DeHan, R. S.: vide Graziadei, P. P. C.

Duckett S. (Philadelphia, PA): The establishment of internal vasculariza

tion in the human telencephalon

107

Fanghanel, J.: vide Schumacher, G. H.

Gee, P.A. (Manitoba): Sex chromatin in vertebrates with possible female heterogamety 127

Gerzeli, G.: vide Mira, E.

Goossens, E.: vide Kroon, D. B.

Graziadei, P. P. C. and DeHan, R. S. (Tallahassee, FL): The ultrastructure of frogs'taste organs 563

Hadziselimovic, F. (Basel): Uber das Chromosomenbild und das Geschlechts-

chromatin der Zwergform des Indischen Zebu (Bos indicus nanus)

Ceylon 418

Halata, Z. (Hamburg): Die Ultrastruktur der Lamellenkorperchen bei Wasservogeln (Herbstsche Endigungen) 362

Jancso, G.: vide Csillik, B.

Kallen, F. C.: vide Webber, R. H.

Kalman, G.: vide Csillik, B.

Kaman, J. und Cerveny, C. (Brno): Die Bildung intrahepataler KoUateralen nach verschieden lokalisiertem Verschluss der Lebervenen beim

Schwein 481 
Kanagasuntheram, R.; Krishnamurti, A.; Ahmed, M.M.; Wong, W.C. and Chan, H.L. (Singapore): Degenerative changes in the optic terminals in the lateral geniculate nucleus of the monkey ....58 Kanagasuntheram, R. and Krishnamurti, A. (Singapore): Eye enuclea tion and substantia nigra $\quad 460$ Karcsu, S.: vide Csillik, B.

Kaufmann, P. (Hamburg): Das Bauprinzip der Muscularis mucosae. . . . 305 Kawamura, K. (Akita): Variations of the cerebral sulci in the cat .... 204 Kozma, M.: vide Csillik, B.

Krause, W.J. (Victoria): Paneth cells of the Echidna (Tachyglossus aculeatus) 435

Krishnamurti, A.: vide Kanagasuntheram, R.

Kroon, D.B.; Goossens, E. and Roozemond, R.C (Amsterdam): Bakerpositive cells in the hypothalamus, especially in the neurosecretory nuclei 287

Mikhail, Y. (Cairo): Intrinsic nerve supply of the thyroid and parathyroid glands 152

Mikhail, Y. (Aleppo): Variations in the response of the immature rat and its arenal gland of ACTH 449

Mira, E.; Gerzeli, G.; Piceis Polver, P. de and Vidi, I. (Pavia): Histofunctional changes in isoproterenol enlarged submaxillary glands of adult male rats 235 Moss, G. S.: vide Das Gupta, T. K.

Motta, P.; Takeva, S. et Nesci, E. (Roma): Etude ultrastructurale et histochimique des rapports entre les cellules folliculaires et l'ovocyte pendant le developpement du follicule ovarien chez les mammiferes 537

\section{Contents VII}

Negm, I.M. (Bhopal): The blood supply of the mouse hypophysis cerebi . . 377

Negm, I.M. (Edinburgh): The vascular blood supply of the pituitary and its development 604

Nesci, E.: vide Motta, P.

Newson, B.: vide Das Gupta, T. K.

$\mathrm{Ng}, \mathrm{K}$. K. F.: vide Wong, W. C.

Nikxowitz, W.J. (Cincinnati, OH): The interaction of hippocampal granular cells with Os04-zinc iodide stain 114

Palacios, E.: vide Sosa, J.M.

Petrovicky, P. (Prague): Structure and incidence of Gudden's tegmental nuclei in some mammals 273

Piceis Polver, P. de: vide Mira, E.

Raja, P.T. K.: vide Bhargava, I.

Rao, G. S.; Sahu, S. and Saigal, R. P. (Pantnagar): The somatotopic arrange ment of motor neurons in the spinal cord of buffalo. A. Brachial

plexus 250

Roozemond, R. C.: vide Kroon, D.B.

Sahu, S.: vide Rao, G. S. 
Saigal, R. P.: vide Rao, G.S.

Schultz, E.: vide Schumacher, G. H.

Schumacher, G. H.; Fanghanel, J. und Schultz, E. (Rostock): Quantita

tive Untersuchungen iiber das postnatale Wachstum von Rattus

norvegicus Berkenhout unter normalen und statisch veranderten

Bedingungen. III. Abdominalorgane (Leber, Milz) 33

Senn, D.G. (Basel): Structure and development of the optic tectum of the snapping turtle (Chelydra serpentina L.)

46

Singh, I. (Rohtak): The distribution of goblet cells in the human small in testine 68

Sit, K. H.: vide Wong, W. C.

Smith, R.B. and Taylor, I.M. (Manchester): Observations on the intrinsic innervation of trachea, bronchi and pulmonary vessels in the sheep 1

Sosa, J.M.; Palacios, E. and Sosa, Haydee, M.S. de (Merida): Heterotopic cerebellar granule cells inside the plexiform layer

91

Sosa, Haydee, M.S. de: vide Sosa, J.M.

Stingl, J. (Pilsen): Zur Ultrastruktur des terminalen Gefassbettes der

Skeletmuskulatur 255

Takeva, S.: vide Motta, P.

Taylor, I.M.: vide Smith, R.B.

Toth, L.: vide Csillik, B.

Vansteenkiste, Y.: vide Willems, G.

Verbeustel, S.: vide Willems, G.

Verma, P. (Bhopal): The early development of Cyprinus carpio var. Commu

nis (Linn.) 388

Vidi, I.: vide Mira, E.

Vizioli, M. R. (Sao Paulo): Macromolecular organization of rat sponge-in

duced granulation tissue as revealed by dichroism

Webber, R. H. and Kallen, F. C. (Buffalo, NY): The sympathetic trunks of

bats 222

Contents

VIII

Willems, G.; Vansteenkiste, Y. and Verbeustel, S. (Brussels): Autoradiographic study of cell renewal in fundic mucosa of fasting dogs . 23

Wong, W.C; Sit, K.H.; Ng, K.K.F. and Chin, K.N. (Singapore): A cho-

linesterase study of the enteric plexuses in the toad (Bufo mela-

nostictus)

82

Wong, W. C: vide Kanagasuntheram, R.

Yokoh, Y. (Tokyo): Early formation of nerve fibers in the human otocyst . 99

New Books - Livres nouveaux - Buchbesprechungen 160,320

Editorial note-Communication de la redaction-Mitteilungen der Redaktion 636 